American Journal of Agricultural and Biological Sciences 6 (2): 214-220, 2011

ISSN 1557-4989

(C) 2011 Science Publications

\title{
Leaf Chlorophyll Fluorescence and Gas Exchange Response to Different Light Levels in Platycerium bifurcatum
}

\author{
${ }^{1}$ Ruzana-Adibah Mohd Sanusi, ${ }^{1,2}$ Ainuddin Ahmad Nuruddin and ${ }^{1,2}$ Hazandy Abdul Hamid \\ ${ }^{1}$ Department of Forest Management, Faculty of Forestry, \\ ${ }^{2}$ Institute of Tropical Forestry and Forest Products, \\ University Putra Malaysia, 43400, Serdang, Selangor, Malaysia
}

\begin{abstract}
Problem statement: Platycerium bifurcatum (Cav.) C. Chr. is epiphytes which lives in forest canopy and commonly used for its ornamental value. In these environments, they were always exposed to many types of stresses such as high light intensity. Light intensity plays an important role in affecting plant's physiological performance. Therefore, the purpose of this study was to investigate physiological responses of $P$. bifurcatum to light stress. Approach: In this study, $P$. bifurcatum were grown under four different Photosynthetic Active Radiation (PAR) levels which were $20 \mu \mathrm{mol} \mathrm{m} \mathrm{m}^{-2}$ (T1), $70 \mu \mathrm{mol} \mathrm{m} \mathrm{m}^{-2}$ (T2), $200 \mu \mathrm{mol} \mathrm{m} \mathrm{m}^{-2} \mathrm{~s}^{-1}$ (T3) and $1500 \mu \mathrm{mol} \mathrm{m}^{-2} \mathrm{~s}^{-1}$ (T4). Leaf gas exchange and chlorophyll fluorescence were used to evaluate the stress response of various levels of light intensity. All measurements were carried out on weekly basis for twelve weeks. Results: Results showed that $A_{\text {net }}$ value of T1, T2 and T3 in the range near to the average $A_{\text {net }}$ value for most epiphytes. Conversely, $\mathrm{T} 4$ showed lower value in $\mathrm{A}_{\text {net }}$ with $1.797 \mu \mathrm{mol} \mathrm{CO} \mathrm{Cm}^{-2} \mathrm{~s}^{-1}$. Fv/Fm ratio in $\mathrm{T} 3$ and $\mathrm{T} 4$ were below 0.8 indicates that there was a sign of stress occurred in these treatments. However $\mathrm{A}_{\text {net }}$ of T3 was not affected although there have been event of photoinhibition observed in the treatment. On the contrary, $\mathrm{T} 4$ was fully affected by high light intensity as there was a reduction of $\mathrm{Fv} / \mathrm{Fm}$ ratio and also $\mathrm{A}_{\text {net }}$. T1 and $\mathrm{T} 2$ of $\mathrm{A}_{\text {net }}$ and $\mathrm{Fv} / \mathrm{Fm}$ ratio values ranged of unstressed plants after subjected to light treatment. Conclusion: Measurement of leaf chlorophyll fluorescence and gas exchange are useful to detection of light stress in $P$. bifurcatum. Different levels of light intensity were significantly affecting physiological attributes of $P$. bifurcatum.
\end{abstract}

Key words: Epiphytic fern, environmental stress, light intensity, photochemical efficiency, tree canopy, physiological attributes, plant chlorophyll fluorescence, Platycerium bifurcatum, Photosynthetic Active Radiation (PAR)

\section{INTRODUCTION}

Forest is a place rich of diversity for many life functions and operated as a habitat for many types of flora and fauna. On the whole, forest canopy plays role as one of the important features of a tree since it performs as a shade and also for shelter for other living or non living things. In accordance to Nadkarni et al. (2004), in the forest environment, there will be changes continuously all through from the top to bottom. Likewise, the canopy area does also alter the average rates of temperature, wind speed, light, sound, relative humidity and turbulence of the forest area. With many types of living population live in and under the canopy, there have been several complexity of the structure and microclimate occurs within crown of a tree such as in some of the Orchidaceae family, it does grow on twigs rather than trunks Nadkarni et al. (2004). Therefore, through this complexity, canopy plants do relatively response in terms of both function and its structure. However, our nature and ecosystem are negatively affected especially by forest degradation which this leads to climate change (Saga et al., 2010). As far as climate change is concerned, for plant that lives under plant canopy such as epiphytes, they are usually exposed to elements of harsh environment and experienced the climate fluctuation. Epiphytes live on other plants and under the tree canopy (Zotz and Hietz, 2001) and they do not consume any nutrients from its host tree since they are fully autotropic (Benzing, 1998). In completion of plants life cycles, they usually accountable to various biotic and abiotic stress (Thomas

Corresponding Author: Ruzana-Adibah Mohd Sanusi, Department of Forest Management, Faculty of Forestry,

University Putra Malaysia, 43400, Serdang, Selangor, Malaysia 
and Kropp, 2011). In this type of habitat and the atmosphere below tree canopy, many types of environmental stress are likely to occur to this type of plant especially stress of high light intensity. Platycerium bifurcatum is one of the epiphytes that live just under forest canopy are exposed to fluctuating environment. $P$. bifurcatum is the epiphytes from the genus of Platycerium in the family of Polypodiaceae. This species has wide distribution and about 15-18 species from this genus mostly lived as epiphytes and grow in the subtropical to tropical lowland forests (Kreier and Schneider, 2006). For instance, species of this genus occurs in lowland tropical rain forests in Malaysia (Perez-Garcia et al., 2010). In addition, ferns are also being utilized as an ornamental plant (Fernandez and Revilla, 2003) and for its landscape aesthetic value.

This plant habitat is usually characterized by highly exposed to the environmental stress such as high light intensity and low water availability. In relation to climate change, through extreme environment such as high light intensity, plants physiological process usually will effected to such stresses. Study on Asplenium nidus (Ainuddin and Najwa, 2009) shows that this species can withstand and survive without watering for 16 weeks. These changes in the environment and stress of plant also affect the physiological process of this plant. Photosynthesis and growth are plant two main characteristics that response to changes in their surroundings (Schurr et al., 2006). In addition, environmental stresses not only affecting plant physiology but also its biochemistry and therefore leads to a significant loss of yield (Tohidi-Moghadam et al., 2009). On the whole, epiphytes showed low photosynthetic capacities and limitation of leaf carbon gain (Zotz and Hietz, 2001). According to Cervantes, et al. (2005), photoinhibition would occur to plants live in high in the canopy and lower photosynthetic rate experienced in plants that grow deep in the canopy. Chlorophyll fluorescence technique has been practiced expansively in determining plant photosynthetic performance (Baker and Rosenqvist, 2004) and determined as Chlorophyll concentration index (Amirjani, 2010). The usage of chlorophyll fluorescence study provides very valuable results as it use a simple and non-destructive method (Paknejad et al., 2009). Chlorophyll fluorescence technique was also reported as a good indicator in determining the stress response. Moreover, extremely excessive light received by plants possibly will damage photosynthetic pigments and structure of plants thykaloid which leads to photodamage (Larcher, 2003) and definitely occurrence of photoinhibition (Stancato et al., 2002). From this, it is vital to know that such exposure to extreme condition as they were subjected to light stress would affect the epiphytic ferns of $P$. bifurcatum in terms of their physiological attributes. Therefore, the objective of this study was to explore the effect of different level of light intensity on physiological attributes of $P$. bifurcatum through gas exchange and chlorophyll fluorescence.

\section{MATERIALS AND METHODS}

Plant materials and experimental design: Plants of similar size of Platycerium bifurcatum were selected to be used for this study. The experiments were conducted at the green house of the Faculty of Forestry, University Putra Malaysia, Serdang, Selangor for twelve weeks starting from April 2009. All of these plants were watered daily prior to the photosynthetic attributes measurement. The amount of light intensity received by each plant was differentiated according to their groups. In this experiment, the plants were subjected to four levels of stress group in four different Photosynthetic Active Radiation (PAR) received by each plant. Three of the group were located under shade cloth and received different level of PAR namely $20 \mu \mathrm{mol} \mathrm{m} \mathrm{m}^{-2} \mathrm{~s}^{-1}$ for first treatment (T1), followed by $70 \mu \mathrm{mol} \mathrm{m} \mathrm{m}^{-2} \mathrm{~s}^{-1}$ in second treatment (T2), $200 \mu \mathrm{mol} \mathrm{m} \mathrm{m}^{-2} \mathrm{~s}^{-1}$ for third treatment (T3). The fourth treatment was located in exposed environment with PAR, $1500 \mu \mathrm{mol} \mathrm{m} \mathrm{m}^{-2} \mathrm{~s}^{-1}$ (T4). In each group there were ten plants and act as replicates to estimate the effects of light intensity on the physiological aspects of $P$. bifurcatum.

Leaf gas exchange and chlorophyll fluorescence measurement: Weekly leaf gas exchange were conducted in the morning which measured by using a Photosynthesis System LI-COR 6400 (LI-COR Biosciences, Inc., Lincoln, NE) and its responses were quantified by measuring the photosynthesis rate $\left(A_{n e t}\right)$, stomatal conductance $\left(\mathrm{g}_{\mathrm{s}}\right)$, transpiration rate $(\mathrm{E})$ and leaf to air vapor pressure deficit calculated based on leaf temperature (D). Three fully expanded leaves from three $P$. bifurcatum plants per stress treatment group were chosen to measure the leaf gas exchange. All measurements were operated at $250 \mu \mathrm{m} \mathrm{s}^{-1}$ of flow rate, reference $\mathrm{CO}_{2}$ concentration of $360 \mu \mathrm{m} \mathrm{CO} \mathrm{mol}^{-1}$ [ppm] and $1200 \mu \mathrm{m}$ photons $\mathrm{m}^{-2} \mathrm{~s}^{-1}$ of quantum flux.

For chlorophyll fluorescence measurement, five plants per stress treatment were selected and measured by using the Handy Pea Chlorophyll Fluorometer (Hansatech Ins.). Three fully expanded leaves were measured for each treatment. Prior to complete the measurement of plant chlorophyll fluorescence, each leaf sample was adapted to darkness by attaching the leaf to a special leaf clip for a period of 20-30 minutes. To determine plant response in terms of chlorophyll 
fluorescence, parameters such as Fo (Fluorescence Origins), Fm (Fluorescence maximum), Fv (variable fluorescence) and Fv/Fm (maximum efficiency of photosystem II) were used to access the effects of Platycerium bifurcatum on light stress.

Data analysis: All data ware analyzed using Analysis Of Variance (ANOVA). This analysis of statistics was performed on all the data using a statistical package of SPSS version 17.0. Further mean separation test was also conducted once significant difference between factors was established and the significant level of $\mathrm{P}$ value was implied at 0.05 . Tukey's test were employed to distinguish a group of mean with the other group mean to find whether they significantly different between each other.

\section{RESULTS}

Statistical summary of Analysis Of Variance (ANOVA) for leaf gas exchange parameters was shown in Table 1. There were significant differences observed for all parameters studied between weeks. For treatment, significant differences were found only for $A_{\text {net }}$ and $E_{L}$. Table 2 shows the mean values of leaf gas exchange parameters for treatments. It was statistically observed that $\mathrm{T} 1 \mathrm{had}$ a higher mean value of $\mathrm{A}_{\text {net }}$ followed by $\mathrm{T} 3, \mathrm{~T} 2$ and $\mathrm{T} 4$. In $\mathrm{T} 2$, the mean values observed in $\mathrm{g}_{\mathrm{s}}$ were found higher than the rest of treatments.

Table 1: The summary of ANOVA for week and treatment parameters of $P$. bifurcatum leaf gas exchange response on light stress

\begin{tabular}{|c|c|c|c|c|}
\hline \multirow[b]{2}{*}{ Week } & \multicolumn{4}{|c|}{ Source of variation } \\
\hline & Parameter & Mean square & $\mathrm{f}$ & $\mathrm{p}$ \\
\hline \multirow{11}{*}{ Treatme } & $\mathrm{A}_{\text {net }}$ & 45.976 & 47.251 & $0.000 * * *$ \\
\hline & $\mathrm{g}_{\mathrm{s}}$ & 0.008 & 19.893 & $0.000 * * *$ \\
\hline & $\mathrm{Ci}$ & 56954.889 & 21.518 & $0.000 * * *$ \\
\hline & $\mathrm{E}_{\mathrm{L}}$ & 0.264 & 10.168 & $0.000 * * *$ \\
\hline & $\mathrm{D}$ & 2.883 & 75.624 & $0.000 * * *$ \\
\hline & & & & \\
\hline & $\mathrm{A}_{\text {net }}$ & 17.793 & 18.286 & $0.000 * * *$ \\
\hline & $\mathrm{g}_{\mathrm{s}}$ & 0.000 & 0.565 & $0.639^{\mathrm{ns}}$ \\
\hline & $\mathrm{Ci}$ & 40037.353 & 1.513 & $0.211^{\mathrm{ns}}$ \\
\hline & $\mathrm{E}_{\mathrm{L}}$ & 0.090 & 3.458 & $0.017 *$ \\
\hline & $\mathrm{D}$ & 0.056 & 1.462 & $0.224^{\mathrm{ns}}$ \\
\hline
\end{tabular}

***: Indicate highly significant at $\mathrm{p}<0.001$, *: Indicate significant at $\mathrm{p}<0.05 ;{ }^{\mathrm{ns}}$ : Indicate not significant

Table 2: The mean values of physiological aspects for treatment observation of responses in different levels of light intensity Treatment

\begin{tabular}{|c|c|c|c|c|}
\hline \multirow[b]{2}{*}{ Parameter } & \\
\hline & $\mathrm{T} 1$ & $\mathrm{~T} 2$ & T 3 & $\mathrm{~T} 4$ \\
\hline $\mathrm{A}_{\text {net }}\left(\mu \mathrm{mol} \mathrm{CO} \mathrm{Cm}^{-2} \mathrm{~s}^{-1}\right)$ & ) $2.678^{\mathrm{a}}$ & $2.426^{\mathrm{a}}$ & $2.632^{\mathrm{a}}$ & $1.797^{\mathrm{b}}$ \\
\hline $\mathrm{g}_{\mathrm{s}}\left(\mathrm{mol} \mathrm{H} \mathrm{O} \mathrm{m}^{-2} \mathrm{~s}^{-1}\right)$ & $0.0352^{\mathrm{a}}$ & $0.038^{\mathrm{a}}$ & $0.036^{\mathrm{a}}$ & $0.0351^{\mathrm{a}}$ \\
\hline $\mathrm{Ci}\left(\mu \mathrm{m} \mathrm{CO}_{2} \mathrm{~mol}^{-1}\right)$ & $281.545^{\mathrm{a}}$ & $250.669^{\mathrm{a}}$ & $277.570^{\mathrm{a}}$ & $296.957^{\mathrm{a}}$ \\
\hline $\mathrm{E}_{\mathrm{L}}\left(\mathrm{mm} \mathrm{H}_{2} \mathrm{O} \mathrm{m}^{-2} \mathrm{~s}^{-1}\right)$ & $0.377^{\mathrm{ab}}$ & $0.408^{\mathrm{a}}$ & $0.367^{\mathrm{ab}}$ & $0.338^{\mathrm{b}}$ \\
\hline $\mathrm{D}(\mathrm{kPa})$ & $1.1458^{\mathrm{a}}$ & $1.1757^{\mathrm{a}}$ & $1.1201^{\mathrm{a}}$ & $1.1462^{\mathrm{a}}$ \\
\hline
\end{tabular}

For $\mathrm{E}_{\mathrm{L}}, \mathrm{T} 4$ recorded the lowest value whereas $\mathrm{T} 2$ showed the highest value. T2 of D recorded the highest mean value. In the regression analyses conducted using Sigma Plot 11.0 (Systat software Inc.), all treatments exhibit moderate relationship between $A_{\text {net }}$ and $g_{s}$ based on Guilford's Rule of Thumb Fig. 1.

Table 3 presents the statistical summary of Analysis Of Variance (ANOVA) for chlorophyll fluorescence parameters. It showed that in all parameters there was significant difference between all chlorophyll fluorescence parameters. Table 4 shows the mean values of chlorophyll fluorescence parameters between treatments. It was observed that T4 had a higher mean value of initial fluorescence (Fo) followed by 3, 1 and T2. Contrary, maximum fluorescence $(\mathrm{Fm})$ value for T1 shows highest value whereas, $\mathrm{T} 4$ shows the lowest.

For maximum efficiency of photosystem II (Fv/Fm) shows that $\mathrm{T} 2$ shows highest value followed by 1,3 and T4. Figure 2 shows the photochemical parameters mean value of Fo, Fm, Fv and Fv/Fm for both weeks and treatments observation. It was observed that chlorophyll fluorescence response towards different light intensity shows that $\mathrm{T} 4$ exhibit the lowest value for parameter of Fv, Fm and Fv/Fm throughout the experiment and exhibit almost the highest Fo value Fig. 2.

Table 3: The summary of ANOVA for Chlorophyll fluorescence parameters between week and different treatment levels of light intensity

\begin{tabular}{llrrr}
\hline $\begin{array}{l}\text { Source } \\
\text { of variation }\end{array}$ & Parameter & \multicolumn{1}{c}{$\begin{array}{c}\text { Mean } \\
\text { square }\end{array}$} & \multicolumn{1}{c}{$\mathrm{F}$} & \multicolumn{1}{l}{$\mathrm{P}$} \\
\hline Week & & & & \\
& Fo & 611887.900000 & 122.944 & $0.000^{* * *}$ \\
& Fm & $1.41 \mathrm{E}+07$ & 113.792 & $0.000^{* * *}$ \\
& Fv & 9002504.000000 & 83.170 & $0.000^{* * *}$ \\
& Fv/Fm & 0.018000 & 6.424 & $0.000^{* * *}$ \\
Treatment & & & & \\
& Fo & 77489.630000 & 15.570 & $0.000^{* * *}$ \\
& Fm & $1.70 \mathrm{E}+07$ & 137.490 & $0.000^{* * *}$ \\
& Fv & $1.86 \mathrm{E}+07$ & 172.206 & $0.000^{* * *}$ \\
& Fv/Fm & 0.307000 & 108.202 & $0.000^{* * *}$ \\
\hline ***. Indicates highly significant at $\mathrm{p}<0.001$ & &
\end{tabular}

Table 4:The mean values of chlorophyll aspects for treatment observation of responses in different levels of light intensity Treatment

\begin{tabular}{lrrrr} 
Parameter & \multicolumn{1}{c}{ T1 } & \multicolumn{1}{c}{ T 2 } & T 3 & \multicolumn{1}{c}{ T 4 } \\
\hline Fo & $476.00000^{\mathrm{a}}$ & $444.75000^{\mathrm{a}}$ & $480.19000^{\mathrm{b}}$ & $490.78000^{\mathrm{b}}$ \\
Fm & $2607.56000^{\mathrm{a}}$ & $2551.03000^{\mathrm{a}}$ & $2187.10000^{\mathrm{b}}$ & $1954.71000^{\mathrm{c}}$ \\
Fv & $2131.56000^{\mathrm{a}}$ & $2106.27000^{\mathrm{a}}$ & $1706.91000^{\mathrm{b}}$ & $1463.92000^{\mathrm{c}}$ \\
Fv/Fm & $0.81353^{\mathrm{a}}$ & $0.82423^{\mathrm{a}}$ & $0.77620^{\mathrm{b}}$ & $0.73342^{\mathrm{c}}$ \\
\hline
\end{tabular}

${ }^{a b c}$ values followed by different letters indicate significant difference at the alpha 0.05 level 


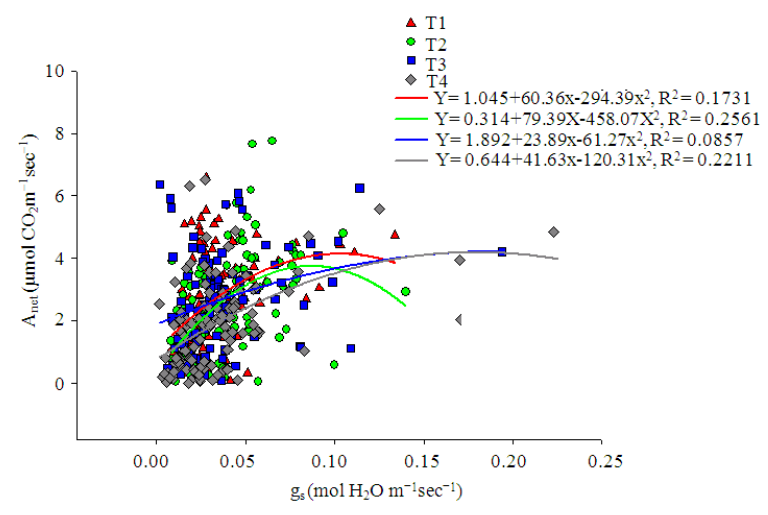

Fig. 1: Regression between photosynthesis rate $\left(A_{\text {net }}\right)$ with stomatal conductance $\left(g_{s}\right)$ in light stress treatment

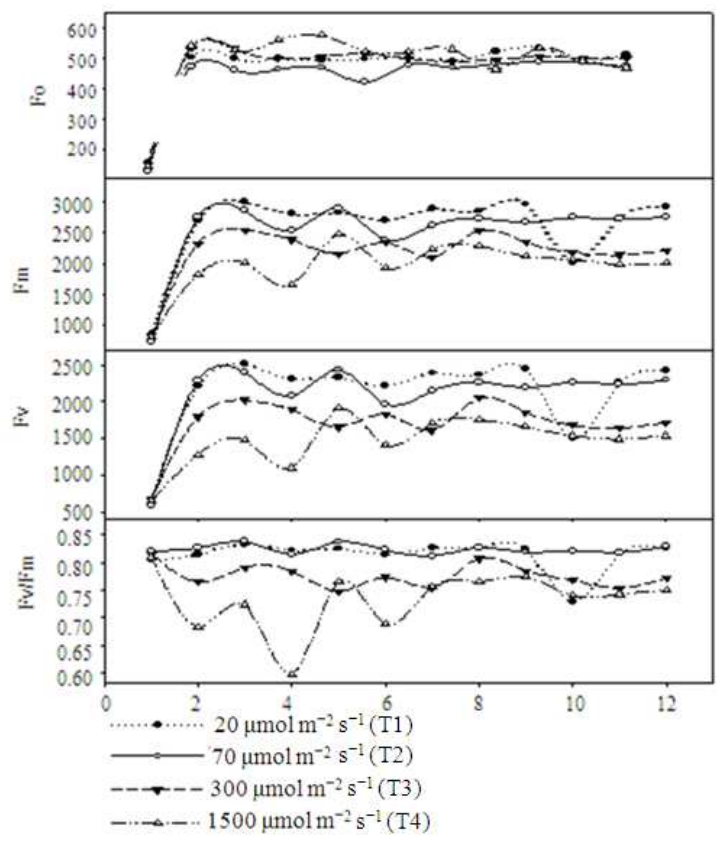

Fig. 2: The mean value of weekly observation for leaf chlorophyll fluorescence parameter at different level of light intensity

\section{DISCUSSION}

The strong interaction between plants and environment reflected either the changes in environment condition will affect the plant function (Hegland et al., 2009). On leaf gas exchange view, the light treatments effects on the physiological attributes of $P$. bifurcatum showed that low photosynthesis rate $\left(\mathrm{A}_{\text {net }}\right)$ value were observed in all treatments Table 2. As reported by Larcher (2003), $A_{\text {net }}$ for plants like ferns, mosses and lichens were examined to be very low if compared to other plants particularly the woody plants and this does caused by assimilation organs of these plants which are not thick. Moreover, it was reported that maximum rates of net photosynthesis of vascular epiphytes mostly yielded low values with average value of $2.6 \mu \mathrm{mol} \mathrm{CO} \mathrm{CO}_{2}^{-2} \mathrm{~s}^{-1}$. The value of both shaded treatment of $\mathrm{T} 1$ and $\mathrm{T} 3$ were observed to maintaining the $A_{\text {net }}$ with approximately around the average value of most epiphytes as stated above. Furthermore, value of $\mathrm{T} 2$ with $2.426 \mu \mathrm{mol} \mathrm{CO} \mathrm{C} \mathrm{m}^{-2} \mathrm{~s}^{-1}$ was only slightly lower than the average $\mathrm{A}_{\text {net }}$ value. This explained the reason that all shaded treatments of $\mathrm{T} 1, \mathrm{~T} 2$ and $\mathrm{T} 3$ could maintain their $A_{\text {net }}$ value near to the average value might due to the lesser limitation of diffusion. This also indicates that this plant still can do photosynthesis well and survive regardless of twelve weeks being subjected to the treatment. Conversely, the value for $A_{\text {net }}$ in exposed plants of $\mathrm{T} 4$ for $P$. bifurcatum is more pronounced substantially lower value than other treatments. This indicates that plant of P. bifurcatum, reacted to environmental stress of high light intensity by reduction in their $A_{\text {net. }}$ The stomatal response to different light intensity showed that the value was higher in exposed plant (T4) than in shaded plants (T1, $\mathrm{T} 2$ and T3). Eventhough there were no significant difference between treatments observed for stomatal conductance $\left(\mathrm{g}_{\mathrm{s}}\right)$ in $P$. bifurcatum throughout the experiment, there was a slight difference between the treatments. The stomatal response to different light intensity showed that $\mathrm{T} 4$ has low value. The lower value in $A_{\text {net }}$ relate to $g_{s}$ value as there are positive relationship between $A_{\text {net }}$ and $g_{s}$ in the regression analysis. The lower value in $A_{\text {net }}$ relate to $g_{s}$ value in $\mathrm{T} 4$. This is also comparable with a study of water stress where decline in leaf photosynthesis rate also leads to decline in the $g_{s}$ under moderate water deficit stress (Zhao et al., 2010). This result as evidence that lower value of $g_{s}$ might point towards to reduction on the $A_{\text {net }}$ value and this was parallel as $g_{s}$ principally affected the diffusional limitation (Larcher, 2003) shows leading in the stomatal limitation. Consequently, this result may due to this condition leads almost to stomatal closure in which stomatal closure generally will reduced the diffusion of ambient $\mathrm{CO}_{2}$ into mesophyll (Elsheery and Cao, 2008.;Franck and Vaast, 2009), thus resulted in the $A_{\text {net }}$ reduction (Cornic, 2002). Higher value of $g_{s}$ in 2 and T3 associated to the high value of $A_{\text {net }}$ if compared to the exposed plants of T4. These observations of higher $\mathrm{g}_{\mathrm{s}}$ and higher $\mathrm{A}_{\text {net }}$ have also been reported by other findings as in citrus plant (Medina et al., 2002). This has been explained by Franck and Vaast (2009) that this condition was linked to lower diffusional limitation. Lower $\mathrm{E}_{\mathrm{L}}$ value in $\mathrm{T} 4$ caused by 
the higher temperature received by the plants thus might lead to loss of water. It was observed that in shaded plants $\mathrm{E}_{\mathrm{L}}$ was higher than exposed plants. The slightly raised in $\mathrm{E}_{\mathrm{L}}$ of shaded plants explained by the evaporation was reduced due to the reduction in leaf and air temperature (Medina et al., 2002). It was observed that $E_{L}$ and $D$ value in $T 2$ was the highest even though this plant was in the shaded condition. This higher value of $D$ explained why the $A_{\text {net }}$ value of this treatment was lower than the other shaded treatments. In accordance to Shirke and Pathre (2004), many studies have reported that high value of $\mathrm{D}$ will lead to limitation in $\mathrm{A}_{\text {net }}$ value but the agreement behind this mechanism is remains unknown.

Chlorophyll florescence has been used to examine the response of stress in plants. In this technique of chlorophyll fluorescence, the adjustment of photosystem II activity was measured through the Chlorophyll $a$ fluorescence changes induced by the stress either directly or not (Percival, 2005). Fv/Fm values were used as an indicator of for photosynthesis quantum yield potential or maximal efficiency in photochemical of photosystem II and useful to study stress which induced changes in PSII (Naumann et al., 2008) It was observed that the Fv/Fm parameter in T3 and T4 showed changes after plants were subjected to light treatments. The trend of reduction in Fv/Fm was detected after week 1, where it showed the highest $\mathrm{Fv} / \mathrm{Fm}$ value and then it fluctuates in decreasing values from week 2 until 7. This phenomenon was supported by by Baker and Rosenqvist (2004) where reduction in Fv/Fm will decrease the photochemical efficiency due to the photoinhibition in Photosynstem II (PS II) reaction centre. PS II damage reflected stress in a leaf of plant (Larcher, 2003). Moreover, growth may decline when placed under low lights (Hassan et al., 2010) while in epiphytic orchid plants, growth was decline due to photoinhibition (Stancato et al., 2002). In relation to this, it was suggested that chlorophyll fluorescence could detect the effect stress then followed by physical symptom of the deterioration on plants (Naumann et al., 2008; Percival and Sheriffs, 2002). In different light level treatment, high light intensity also inhibits maximal photochemical efficiency of PS II as observed in T3 and T4. The ratio was decreased and statistically significant which leads to the indication of the efficiency of the quantum yield of photosystem II was suffered from light stress. This related that in high light intensity, reduced the Fv/Fm ratio that indicates photodamage of PS II and suggested that it was associated with CAM indication (Rut et al., 2008). Moreover, 0.8 was the value for Fv/Fm which indicated that plants leaf was in good health condition (Oyetunji et al., 2007). In T4, it was observed that it received the lowest Fv/Fm, highest Fo and the ratio value was lower than 0.8. Therefore, this indicates that photosynthetic system of the leaves has been in maximal damage (Percival, 2005). On the other hand, T3 also shows the same value below the healthy condition. In relation to leaf gas exchange capacity, eventhough plants in T3 (PAR, $200 \mu \mathrm{mol} \mathrm{m} \mathrm{m}^{-2} \mathrm{sec}^{-1}$ ) have been in stress condition as its ratio of $\mathrm{Fv} / \mathrm{Fm}$ was lower than 0.8 , it does not affect the plant's $\mathrm{A}_{\text {net }}$ as the value was within the average epiphyte's $A_{\text {net }}$ value. On the other hand, for the exposed plants of T4, it showed that there was parallel result for their Fv/Fm ratio and $\mathrm{A}_{\text {net }}$ value. As it has been the most stressed plants treatment as their Fv/Fm ratio was the lowest and below 0.8 , it was also showed that the light stress does affect this treatment by the reduction in their $A_{\text {net }}$ as the value of this parameter was far below from the average $A_{\text {net }}$ value for most epiphytes. From these findings we could say that the highest light intensity treatment of exposed plants, T4 which was affected more compared to 3, 1 and followed by T2. Both 1 and T2 of shaded plants showed Fv/Fm above the value of 0.8 . Additionally, mean value of Fv/Fm in treatment 2 which is 0.83 was matching to the value in 22 British plant species (Johnson et al., 1993). This indicates that this plant of both treatment were in good health condition. Moreover, 1 and T2 stay in the range of healthy plants even after given treatment. From this, it signified that there was evidence of the absence for yield loss of photosystem II in these plants photochemistry.

Therefore, this explained that plants in both treatment of $\mathrm{T} 1$ and $\mathrm{T} 2$ does not affected by light stress which indicates that these range of light intensity are suitable for $P$. bifurcatum plants to live in without affecting its photosynthetic apparatus where T2 $\left(70 \mu \mathrm{mol} \mathrm{m} \mathrm{m}^{-2} \mathrm{~s}^{-1}\right)$ was found the most optimal value of light intensity for this epiphytic plant. Significant difference in all weekly observation of leaf gas exchange and chlorophyll fluorescence parameter showed that there were distinct changes in physiological attributes throughout twelve weeks of examination. Thus indicates that light stress was affecting the physiological attributes of $P$. bifurcatum plants.

\section{CONCLUSION}

In the leaf gas exchange response, all $\mathrm{T} 1, \mathrm{~T} 2$ and T3 showed $A_{\text {net }}$ approximately near to the average $A_{\text {net }}$ value for most epiphytes while the exposed plants of $\mathrm{T} 4$ shows lower value in $A_{\text {net. }}$ This may also due to the relation with $g_{s}$ that leads to the involvement in diffusional limitation. From these findings, the response of plants towards gas exchange indicates that by reduction in their $\mathrm{A}_{\text {net, }}$ in $\mathrm{T} 4$ plant of $P$. bifurcatum 
showed response to environmental stress of high light intensity. Chlorophyll fluorescence technique has proved to be a good index as a screening or plant health status of $P$. bifurcatum under light stress. The highest light intensity treatment or exposed plants (T4) showed lowest in chlorophyll parameters of $\mathrm{Fm}, \mathrm{Fv}$ and $\mathrm{Fv} / \mathrm{Fm}$ where the value of $\mathrm{Fv} / \mathrm{Fm}$ in higher levels of light intensity of T3 and T4 were below 0.8 shows there was a sign of stress occurs to plants that lived in these treatments. Conversely, for lower levels of light intensity of T1 and T2 stay in the range of unstressed plants even after given different treatment. Nevertheless, T3 does not showed any reduction in $\mathrm{A}_{\text {net }}$ eventhough the plant was in stress provision. However, exposed plants of $\mathrm{T} 4$ showed reduction of $\mathrm{A}_{\text {net }}$ as well as Fv/Fm ratio. From this evidence, this indicates that these plants were affected by light stress. As conclusion, from these findings we could verify that the photosynthesis characteristics of $P$. bifurcatum were affected by different levels of light intensity.

\section{ACKNOWLEDGEMENT}

We would like to thank every individual involved in this project for their technical assistance, helpful and thoughtful suggestion. Our deepest gratitude also to Physiology Laboratory for allowing us to use equipment and helped in handling the measurements. We also thank Institute of Tropical Forestry and Forest Products (INTROP) for hosting a workshop that helped expand and improve this study. This study was a part of the research project No. 03/01/07/0035RU which was funded by the Research University Grant Scheme (RUGS).

\section{REFERENCES}

Ainuddin, N.A. and D.A.N. Najwa, 2009. Growth and physiological responses of Asplenium nidus to water stress. Asian J. Plant Sci., 8: 447-450.

Amirjani, M.R., 2010. Salinity and photochemical efficiency of wheat. Int. J. Botany, 69: 273-279.

Baker, N.R. and E. Rosenqvist, 2004. Applications of chlorophyll fluorescence can improve crop production strategies: An examination of future possibilities. J. Exp. Bot., 55: 1607-1621. DOI: 10.1093/jxb/erh196

Benzing, D.H., 1998. Vulnerabilities of tropical forests to climate change: The significance of resident epiphytes. Climatic Change, 39: 519-540. DOI: 10.1023/A:1005312307709

Cervantes, S.E., E.A Graham and J.L. Andrade, 2005. Light microhabitats, growth and photosynthesis of an epiphytic bromeliad in a tropical dry forest. Plant Ecol., 179: 107-118. DOI: 10.1007/s11258004-5802-3
Cornic, G., 2002. Drought stress inhibits photosynthesis by decreasing stomatal aperture- not by affecting ATP synthesis. Trends Plant Sci., 5: 187-188.

Elsheery, N.I. and K.F. Cao, 2008. Gas exchange, chlorophyll fluorescence and osmotic adjustment in two mango cultivars under drought stress. Acta Physiol Plant, 30: 769-777. DOI: 10.1007/s11738008-0179-X

Fernandez, H. and M.A. Revilla, 2003. In vitro culture of ornamental ferns. Plant Cell, Tiss Organ Culture, 73: 1-13. DOI: 10.1023/A:1022650701341

Franck, N. and P. Vaast, 2009. Limitation of coffee leaf photosynthesis by stomatal conductance and light availability under different shade levels. Trees Struct Funct., 23: 761-769. DOI: 10.1007/s00468009-0318-z

Hassan, A., A. Mohamad, A. Arifin, M. Maid and J. Kodoh et al., 2010. Effects of light intensity on Orthosiphon stamineus benth. seedlings treated with different organic fertilizers. Int. J. Agric. Res., 5: 201-207.

Hegland, S.J., A.Nielsen, A. Lazaro, A.L. Bjerknes and O. Totland, 2009. How does climate warming affect plant-pollinator interactions? Ecol Lett, 12: 184-195. DOI: 10.1111/j.1461-0248.2008.01269.x

Johnson, G.N., A.J. Young, J.D. Scholes and P. Horton, 1993. The dissipation of excess excitation energy in British plant species. Plant, Cell Environ., 16: 673-679. DOI: $10.1111 / \mathrm{j} .1365-$ 3040.1993.tb00485.x

Kreier, H.P. And H. Schneider, 2006. Phylogeny and biogeography of the staghorn fern genus Platycerium (Polypodiaceae, Polypodiidae). Am. J. Botany, 93: 217-225.

Larcher, W., 2003. Physiological Plant Ecology: Ecophysiology and Stress Physiology of Functional Groups. 4th Edn., Springer, USA., ISBN-10: 3540435166, pp: 513.

Medina, C.L., R.P. Souza, E.C. Machado, R.V. Ribeiro and J.A.B. Silva, 2002. Photosynthetic response of citrus grown under reflective aluminized polypropylene shading nets. Scientia Hortic., 96: 115-125.DOI: 10.1016/S0304-4238(02)00085-7

Nadkarni, N.M., G.G. Parker, H.B. Rinker and D.B. Jarzen, 2004. The nature of forest canopy. In: Forest Canopies, Lowman, M.D. and H.B. Rinker (Eds.). Academic Press, USA., pp: 3-10. ISBN-10: 0-12-457553-6

Naumann, J.C., D.R. Young and J.E. Anderson, 2008. Leaf chlorophyll fluorescence, reflectance and physiological response to freshwater and saltwater flooding in the evergreen shrub, Myrica cerifera. Environ. Exp. Bot., 63: 402-409. DOI: 10.1016/j.envexpbot.2007.12.008 
Oyetunji, O.J., I.J. Ekanayake and O. Osonubi 2007. Chlorophyll fluorescence analysis for assessing water deficit and Arbuscular Mycorrhizal Fungi (AMF) inoculation in Cassava (Manihot esculenta Crantz). Adv. Biol. Res., 1: 108-117.

Paknejad, F. M. Mirakhori, M.J. Al-Ahmadi, M.R. Tookalo and A.R. Pazoki et al., 2009. Physiological response of soybean (Glycine max) to foliar application of methanol under different soil moistures. Am. J. Agri. Biol. Sci., 4: 311-318. DOI: 10.3844/ajabssp.2009.311.318

Percival, G.C. and C.N. Sheriffs, 2002. Identification of drought-tolerant woody perennials using chlorophyll fluorescence. J. Arboric., 28: 215-223.

Percival, G.C., 2005. The use of chlorophyll fluorescence to identify chemical and environmental stress in leaf tissue of three oak (Quercus) species. J. Arboric., 31: 215-227.

Perez-Garcia, B., A. Mendoza-Ruiz, S. EspinosaMatias and L.D. Gomez-Pignataro, 2010. Gametophyte morphology of Platycerium andinum baker and Platycerium wandae Racif. Micron, 41: 806-813. DOI: 10.1016/j.micron.2010.05.005

Rut, G., J. Krupa, Z. Miszalski, A. Rzepka and I. Slesak, 2008. Crassulacean acid metabolism in the epiphytic fern Patycerium bifurcatum. Photosynthetica,. 46: 156-160. DOI: 10.1007/s11099-008-0026-8

Saga, B.T., O.H. Ahmed, A.S. Jamaluddin, H. AbdulHamid and S. Jusop et al., 2010. Selected soil morphological, mineralogical and sesquioxide properties of rehabilitated and secondary forests. Am. J. Environ. Sci., 6: 389-394. DOI: 10.3844/ajessp.2010.389.394
Shirke, P.A. and U.V. Pathre, 2004. Influence of leafto-air Vapour Pressure Deficit (VPD) on the biochemistry and physiology of photosynthesis in Prosopis juliflora. J. Exp. Bot., 55: 2111-2120. DOI: $10.1093 /$ jxb/erh229

Schurr, U., A. Walter and U. Rascher, 2006. Functional dynamics of plant growth and photosynthesis- from steady-state to dynamics-from homogeneity to heterogeneity. Plant, Cell Environ., 29: 340-352. DOI: 10.1111/j.1365-3040.2005.01490.x

Stancato, G.C., P. Mazzafera and M.S. Buckeridge, 2002. Effects of light stress on the growth of the epiphytic orchid Cattleya forbesii Lindl. X Laelia tenebrosa Rolfe. Rev. Bras. Bot. DOI: 10.1590/S0100-84042002000200011

Thomas, E. and B.R. Kropp, 2011. Some effects of abiotic stress on infection of dyer's woad (Isatis tinctoria L.) by Puccinia thlaspeos C. Schub.: Implications for biological control. Am. J. Agri. Biol. Sci., 6: 45-51. DOI: 10.3844/ajabssp.2011.45.51

Tohidi-Moghadam, H.R., A.H. Shirani-Rad, G. NourMohammadi, D. Habibi and M. Mashhadi-AkbarBoojar, 2009. Effect of super absorbent application on antioxidant enzyme activities in Canola (Brassica napus L.) cultivars under water stress conditions. Am. J. Agri. Biol. Sci., 4: 215-223. DOI: 10.3844/ajabssp.2009.215.223

Zhao, D., B. Glaz and J.C. Comstock, 2010. Sugarcane response to water-deficit stress during early growth on organic and sand soils. Am. J. Agri. Biol. Sci., 5: 403-414. DOI: 10.3844/ajabssp.2010.403.414

Zotz, G. and P. Hietz, 2001. The physiological ecology of vascular epiphytes: current knowledge, open questions. J. Exp. Bot., 52: 2067-2078. DOI: 10.1093/jexbot/52.364.2067 